\title{
THE ORIGIN OF SOCIALIST REFORMISM IN FRANCE*
}

PRELUDE: THE OPPOSITION TO MARX IN THE INTERNATIONAL

Although the International Workingmen's Association is often called the Marxian International, it was at no time safely under the control of Karl Marx. The spirit of Marx, however, was the strongest single influence in the organization from its beginning, and from 1868, when the Proudhonians had suffered defeat at the Brussels Congress, to 1872, when Bakunin's opposition proved too strong to be overcome, Marx possessed more power in the organization than anyone else. Yet this power collapsed in 1872: Although formally Marx was the victor at the Hague Congress, actually in the conflict with Bakunin it became evident that Marx's position was disintegrating. What were the reasons?

"Marx accused his opponent of the intention to introduce into the Association ideological disorder, the spirit of [political] abstentionism and of federalism, in the utopian desire to create a communal organization without government. Bakunin, in his turn, criticized Marx for wanting to impose on the International a unified dogma and a party discipline in order to create a regime of authoritarian communism first in the Association and then in the state (dans les gouvernements)."1 Unfortunately for Marx and for the unity of the workers' movement, many members of the International who by no means believed in a "communal organization without a government" and perhaps were not

- The author wishes to express his gratitude to the Institute of International Studies at the University of California at Berkeley for financial support in meeting expenses incurred in the collection of material; also to Monsieur Coutarel, librarian of the Prefecture de police in Paris, for permission to use the files of the Préfecture; and to the staff of the Internationaal Instituut voor Sociale Geschiedenis in Amsterdam, especially to Mr T. Haan, Mr G. Langkau and Miss Maria Hunink, as well as to Mr Yves Collart and Mr Miklos Molnar of the Institut Universitaire de Hautes Etudes Internationales in Geneva, for bibliographical advice and assistance.

1 Miklos Molnar, Le Déclin de la Première Internationale. La Conférence de Londres de 1871, Genève: Droz, 1963, p. 158. 
even much worried about a future "regime of authoritarian communism", shared Bakunin's suspicion that Marx wanted to establish in the International a sort of personal dictatorship which they were unwilling to tolerate. In this context it is irrelevant whether the suspicion was justified, ${ }^{1}$ and equally irrelevant whether Bakunin was as consistently anti-authoritarian as he pretended, or was believed, to be. ${ }^{2}$ The important point is that from 1871 on the attacks of convinced anarchists coincided with rising resentment against Marx's leadership among groups on which he had so far relied for support.

Perhaps the best illustration of this point can be found in the defection of British trade unionists from the Marxian camp - of men who had been among Marx's loyal supporters during most of the life of the International. Whatever may have been the peculiar reasons for the opposition of the Federal Council of the International for Britain to the leadership of Marx and Engels, ${ }^{3}$ it certainly proves that even

1 At no time had Marx been able to play the autocrat in the International Workingmen's Association. To the extent that he was in a position of leadership, he kept that position by balancing Proudhonians, Trade Unionists, at times Blanquists, Bakuninists, land reformers and a number of non-descript groups against each other; his role resembled far more that of a diplomat than that of a dictator. However little this role may have suited his temperament, he played it with considerable patience, and merely vented his inner rebellion in letters to Engels. Did he see a chance to change the character of his leadership in 1871-2? Miklos Molnar has advanced the hypothesis that Marx, at the time of the London Conference of the International, planned to turn the organization into a "unified and disciplined Party" (l.c. pp. 133ff., esp. 141). This does not seem convincing to me. To be sure, Marx asked for an extension of the powers of the General Council of the International, to stop the growth of Bakunin's influence and possibly also to meet emergencies arising from the governmental persecution of the International in the wake of the Commune defeat. But the new tactical weapon would not have changed the fundamental dependence of Marx's position on a balance of mutually antagonistic forces which he had to keep with the very limited number of his own convinced followers.

"Bakunin's "International Alliance of Social Democracy", founded in 1868, was a conspiratorial organization. See Julius Braunthal, Geschichte der Internationale, Hannover: J. H. W. Dietz, 1961, Vol. I, p. 187. Any such organization needs a much stricter discipline than an organization like the International Workingmen's Association which is operating in the open, and the structure of the Alliance seems to prove that Bakunin was not unaware of this need.

s Prior to the creation of the Federal Council for Britain at the London Conference of September 1871, the General Council had functioned as the integrating body for the local branches in Britain, thus emphasizing that Britain "cannot be treated as just one country among many; it must be treated as the metropolis of capital." (Karl Marx in a "Private Communication" of January 1870 to members of the International, reprinted in Molnar, op. cit., p. 122.) Marx gave up this position in 1871, probably to gain the support of John Hales and other British trade unionists in his struggle against Bakunin. He did gain their support at the London Conference, but a year later at the Hague the trade unionists had already defected from his camp. 
members of the International who were entirely without sympathy with Bakunin's stand on the controversial issues had been alienated by Marx. No group of Internationalists could be farther from political abstentionism than the British trade union leaders who a few years previously had concentrated all their efforts on obtaining an extension of suffrage and who now were preparing for the exploitation of that success through an increase of labor influence in parliament; nor was any group within the International less inclined to adopt the conspiratorial strategy of Bakunin. Moreover, the British trade unionists were at that time confirmed believers in reformism: In most sections of the British working class, and certainly among the leaders of the unions, the revolutionary spirit had vanished in the Chartist debacle of 1848 . If the lack of a will to revolution separated them from Marx, it ought to have separated them far more from Bakunin and ought to have induced them to continue at least tactical cooperation with Marx and Engels. But the British representatives at the Hague Congress voted against the General Council and such important British labor leaders as John Hales and John Eccarius appeared as delegates at the Geneva Congress of the "anti-authoritarian" International.

The British trade unionists were not the only group whose attitude toward the Marx-Bakunin conflict was determined not so much by opinions about the issues at stake as by animosity against Marx and his intimates. The Lassallean Universal German Workingmen's Association declared its solidarity with Bakunin's International and sent representatives to the latter's Congress in Brussels in 1874. In 1876, at the Congress of Bern, there even appeared a representative of the now unified German Social Democracy - again a Lassallean, Vahlteich. ${ }^{1}$ Yet Lassalle, even more consistently than Marx himself, had been a believer in universal suffrage and in the vital importance of the parliamentary weapon for the workers; so was his successor, Johann Baptist von Schweitzer. By their opinions, they belonged on the side of Marx; since they stood on the other side, personal resentment and the fear lest Marxian leadership would crush the autonomy of national groups must have been decisive.

In the face of the cautious strategy and even patience which Marx had practised in the International, how can it be explained that he was accused of autocratic methods, that resentment against him accumulated, and that finally groups which had little in common except their suspicion of his intentions banded together to make his leadership impossible? The most plausible answer is that his style of leadership was more provocative than the essence of his strategy. There is an

1 See Julius Braunthal, Geschichte der Internationale, Vol. I, p. 198. 
abundance of evidence to show that Marx was not a pleasant person to deal with, that he was inconsiderate and often hurt the feelings not only of enemies but also of associates, who then became enemies. The circumstances of his life, his penury and sickness, may make these attitudes more understandable, but they also had some roots in Marxian theory. The belief to have discovered the arcanum of history, its driving forces, the form of its process and the goal toward which this process was directed, was a source of superiority feelings which a man of Marx's temperament could control only with the greatest of difficulty, and never completely. Moreover, whereas the master at least intellectually realized that the unenlightened must be given time to assimilate the truth, and that nothing could be gained by trying to bludgeon them into conformity with the right doctrine, this wisdom was almost entirely lacking in some of his disciples, and their actions increased the resentment against the head of the school.

\section{II}

MODERATES, ANARCHISTS AND SOCIALISTS IN POST-COMMUNE FRANCE

Knowledge of the virtual coalition against Marx, formed in the early 1870 's within the International by anarchists with men of very different persuasion, some of them confirmed or potential reformists, is essential for an understanding of developments within French socialism in the 1880 's. The major aspect of this development is the emergence of an anti-Marxian tendency among the French socialists, motivated largely by the same mistrust against the autocratic inclinations of Marx and his intimates which had cemented the anti-Marxian bloc in the International. There were also differences, of course: In the struggle within the International, the anarchists had been in the forefront, and other malcontents, including some reformists, had joined them as auxiliaries. In the later struggles in France, the leadership lay with people who had ceased to be anarchists in the full sense; although they had retained some trends of anarchist thinking, and would have reacted violently anyone who might have questioned the firmness of their belief in the inevitability of revolution, most of them were potential reformists. The break between this group and the French Marxists takes its historic significance from the fact that then and there the seeds were sown for the kind of reformism which later flowered in the ideas, words and deeds of Jean Jaurès. But the seeds took years to germinate, and this difficult process of germination will be examined on the following pages. That the emergence of reformism within the French socialist movement during the 1880's encouraged Georg von Vollmar and Eduard Bernstein to develop their "revisionism" in Germany in the next decade, is 
inherently plausible but cannot be strictly proved. In any event, the process by which the French anti-Marxists became conscious of their reformism belongs to the pre-history of the great split which rent the socialist movement apart in the twentieth century. ${ }^{1}$

The defeat of the Commune had been a tremendous set-back for the socialist movement in France. Almost all the socialist leaders had been participants in the upheaval or had openly sympathized with it, and, if they had survived the combat and the subsequent executions, were imprisoned or in exile; a few, who had stayed on the Versailles side like Louis Blanc and the Proudhonist Henri Tolain - had compromised themselves in the eyes of the workers. But French socialism recovered more quickly than had appeared probable right after the debacle, mainly because the middle-class republicans could not afford a longdrawn-out policy of repression against the socialist workers whom they needed for the defence of the republic. By the fall of 1880 the exiles had returned; even earlier, in 1879 , the resurrection of political socialism in France had been visibly initiated at the Marseille Workers' Congress.

At this congress the decisive battle was between the "collectivists" a name then used for all determined socialists ${ }^{2}-$ and a group called the "moderates" or "cooperators". The former were under the leadership of Jules Guesde and Paul Brousse - with Benoit Malon and Jean Allemane, who had not yet returned from exile, in the background; these were the principal actors in the drama that will be described below. The leader of the moderates was Joseph Barberet. In the first years after the Commune, when no socialist propaganda was permitted and even militant trade unionism was impossible, he had rallied the workers around the idea of cooperatives, both of the producer and the consumer variety. In 1879 , this moderatism, which in the opinion of most contemporaries stood outside the pale of socialism, still drew considerable strength from the experience that restraint had helped to keep at least traces of the movement alive in the most difficult period; also from the Proudhonian tradition, which had always been anti-revolutionary and

1 There are of course earlier examples of a division between evolutionary and revolutionary socialists. One may think of the cleavage between Proudhonians and Marxists in the International, or of the antagonism between Gemässigte and Radikale in Austria during the 1870's. Yet from none of these earlier splits leads a direct line to the great rift in the socialist and labor movement during and after the First World War.

This was the prevailing usage. Some confusion, however, was created by the attempt of the followers of Jean de Colins, who were in the main land reformers and for the rest supporters of limited meliorative legislation, to appropriate the name collectivists. See e.g. Samuel Bernstein, The Beginnings of Marxian Socialism in France, New York: Social Science Studies, 1933, pp. $105 \mathrm{ff}$. 
even skeptical of or antagonistic to political power, and finally from an anti-intellectual tendency which has often played a role in the workers' movement - the idea that only workers should lead workers, because intellectuals would involve the movement in fruitless doctrinal disputes, and in any event did not know the workers' needs from their own experience; concentration on the practical work of the cooperatives might make it possible, it was thought, too keep the movement strictly proletarian. ${ }^{1}$

Against Barberet and his moderates, however, operated the memory of the Commune. The collectivists

"saw in the members of the government circles and the men of the ruling classes or of the moderate parties the spokesmen for the perpetrators of the massacres of 1871 , for the conquerors of the Commune - of that Commune of which the collectivists claimed to be the successors. This produced the kind of aggressiveness (emportement) and defiance which is characteristic of parties involved in a great struggle, and this mood was still growing because hatred is as contagious as the enthusiasm of brotherhood."2 The radicalism engendered by the memory of the bloody reprisals of 1871 found a sufficient echo in the minds of many worker delegates to give the collectivists a complete victory at Marseille. ${ }^{3}$ A resolution calling for social ownership of all means of production was enacted with a two to one majority over the opposition of the cooperators.

This victory could be won because collectivists and anarchists stood together. At the next congress too (Le Havre, 1880) these two factions maintained their collaboration. After having separated from the cooperators, they constituted themselves as a party, for which the name

1 This mistrust against intellectuals has perhaps played an even greater role in the labor movement of France than in that of other countries. It was destined to be important in the separation of Jean Allemane and his friends from the Broussists in 1890, as was shown by the words of a delegate to the (Allemanist) Regional Congress of the Union Fédérative du Centre: "We want neither Guesde nor Brousse; we want only unknown people (que d'obscures)" (L'Egalité, March $16,1891)$. The intellectuals, of course, would never be unknowns.

2 Benoît Malon, "Le Programme de 1880 (Suite des Collectivistes français)", in: Revue Socialiste, Vol. V, 1887, p. 40.

3 There remained, however, a considerable element in the French working class which was not carried away by this radical wave. Many trade unionists in the South-West and the North were "anxious for immediate reforms and particularly hostile to extremist statements, to the threats and challenges (sommations) which were the fashion among the men of the Egalite - who carried with them the men of the Proletaire [...] - and the anarchists" (Malon, ibid.). L'Egalite was in this period a Marxist paper, Le Prolétaire had a broader ideology and eventually became the main organ of the Fédération des travailleurs socialistes. 
Fédération des travailleurs socialistes was adopted. ${ }^{1}$ The Le Havre Congress approved, as a "minimum program" and as a platform for the elections of 1881, a text written by Marx, Engels, Guesde and Lafargue and already endorsed, a few months earlier, at the Paris Congress of the Federation of the Central Region - one of the socialist groupings which had been formed before the national party was constituted. ${ }^{2}$ Some qualifications, however, were added to the adoption of the "minimum program" at Le Havre: The organizations in the electoral districts were invited to formulate a more farreaching program (un programme plus accentué) if they felt that this was proper under the conditions of their political battlefields; furthermore, the motion by which the Havre Congress made the minimum program its election platform contained the clause: "It is understood that the program constitutes only one possible expression of demands (n'établit qu'une des formes du groupement) and that the unchangeable goal of the proletariat is to activate the revolution with all possible means." The congress also declared that the party regarded "the municipal and legislative elections of 1881 as a final test, and that if they do not lead to results, will from then on devote itself purely and simply to revolutionary action."3

Like the Erfurt program which the German Social Democratic party adopted in 1891, the minimum program was divided into two parts. The first lists a number of democratic and reformist demands, from abolition of restrictions on the freedom of the press and a minimum wage law to the abrogation of the right of inheritance for non-descendants and its limitation to frs 20.000 estate value in the direct line. The second, general part begins with an emphatic demand for political liberty, a rejection of political abstentionism and a commitment to the need for an independent labor party. These declarations are followed by an exposition of the economic philosophy of revolutionary socialism, culminating in the idea that individual property must be superseded by collective property.

It is difficult to explain why the anarchists ever consented to the adoption of this program, even with qualifications, since it emphasized the necessity of political action; the prospect that after the 1881 elections the party might abandon all striving for influence in parliament

1 The name of the new party underwent some variations in the 1880 's. On many occasions the party publications liked to call it le parti ouvrier, which after the expulsion of the Marxists was confusing since the latter adopted the name of Parti ouvrier français.

${ }^{2}$ For the text of the program adopted at Paris, see Seilhac, Les Congrès ouvriers en France (1876-1897), Paris: Colin, 1899, pp. 57ff.; for the text of the Havre resolution, ibid., p. 73.

L.c., p. $76 f$. 
in favor of revolutionary action was hardly a sufficient compensation for the endorsement of a philosophy opposed to anarchist principles. It is no easier to explain why the collectivists, when together with the anarchists separating from the cooperators, apparently joined the former in shouting: "Vive l'anarchie!"1 It seems that the emotions which called for a common front of all the anti-moderates were so strong as to make the factions within that front temporarily forget their differences.

It was not for long that the differences remained forgotten. The anarchists soon discovered their basic disagreement with the spirit of the "minimum program", and the propaganda of the other leaders of the new party, especially the speeches and articles of Jules Guesde, made them think that they had little in common with their associates. Struggles broke out shortly after the Havre Congress, and "soon there were no anarchists left in the Workers' Party". ${ }^{2}$

It would be rash to assume, however, that with the departure of the "pure" anarchists all anarchist tendencies vanished from the Fédération des travailleurs socialistes. The "official" dividing line between anarchists and socialists was marked by the rejection or affirmation of political action; but was it not possible to affirm political action for the working class and still retain a good deal of skepticism about the state not only in the distant future when it would die out even in the opinion of orthodox Marxists, but also in the "period of transition"? It would seem a priori probable that this was precisely the feeling of many French workers. Their common sense told them not to neglect the weapon that was at hand, and to use the propagandistic potentialities of election campaigns, but this attitude was quite compatible, at least for the moment, with hostility toward the state. Eugène Pottier, the author of the song The International, had in another song the worker say to the bourgeosie:

"Je ne mets pas ma main loyale

Dans l'amalgame corrumpu."3

At first sight these lines read like a plea for abstentionism, but the verses were written to celebrate the results of socialist participation in the elections of 1881 and every stanza closes with the refrain:

"Salut aux quinze mille voix!"

It seems that the repudiation of all bourgeois parties was based on the same kind of feeling - perhaps with some difference in degree - as the

1 Seilhac, op. cit., p. 62.

- Georges Weill, Histoire du mouvement social en France 1852-1924, Paris: Alcan, 1924, p. 236.

Quoted by Alexandre Zévaès, Le Socialisme en France depuis 1871, Paris: Editions France-Empire, 1947, p. 115. 
repudiation of the total parliamentary apparatus; the tone of many articles and speeches which emerged from the Fédération des travailleurs socialistes during the early 1880 's confirms that impression. This affinity with anarchist sentiment is very understandable in view of the background of some of the leaders of the party.

\section{III}

\section{THE LEADERS OF THE NEW PARTY}

All the leaders of the Féderation had served an important part of their political apprenticeship during their post-Commune exile. Paul Brousse and Benoît Malon had been on the anarchist side. As late as the Ghent Congress of 1877, Brousse had maintained the intransigent position of the Bakuninists; ${ }^{1}$ Malon, who had never been a Bakuninist in the full sense, had already begun to veer to the side of "legalism", which on the Italian scene - Italy was Malon's principal field of operation in that period - meant a repudiation of conspiratorial activities and an affirmation of both trade unionism and political socialism, although a number of Italian "legalitarians", and especially Malon, still put more emphasis on the former than on the latter. ${ }^{2}$ Malon became a major force in turning the Italian socialists away from Bakunin's side which they had supported almost without reservation, and in 1879 he gave the former anarchist leader Andrea Costa the advice "to follow Marx, but not to neglect the idealistic factors in history". 3

Jules Guesde was originally a radical republican and became a socialist through the Commune experience. On his relationship to anarchism during his exile in Switzerland and Italy the evidence is somewhat

1 Richard Hostetter, The Italian Socialist Movement, New York: Van Nostrand, 1958, Vol. I, p. 391.

2 L.c., pp. 369,375 and passim.

3 L.c., p. 415. Hostetter is quoting from Lilla Liparini, Andrea Costa, Milano: Longanesi, 1952. Georges Weill describes Malon's position, at the time of his return to France, as follows: "Malon was an outspoken revolutionary, who in violent language denounced the misdeeds of the bourgeoisie against the proletariat. But he insisted that one should think of how to achieve practical results : 'We have been overfed with phraseology and impotent dogmatism; it is necessary to penetrate to the heart of the situation and to see things not as we would wish them to be but as they are.' Concerning himself more and more with theoretical studies, he taught a doctrine similar to that of Marx in the field of economics but thought of complementing it by an ethical doctrine derived from the ideas of the old French socialists." (Georges Weill, op. cit., p. 240.) 
conflicting, ${ }^{1}$ but by 1876 , having returned to France, he either was already a devoted follower of Marx or became one shortly afterwards. With Paul Lafargue he formed the inner Marxist circle in France, and he supplied much of the energy for the reconstruction of the French socialist movement.

Little is known about the life of Jean Allemane prior to his return to France, and even for some time afterwards it is difficult to obtain a completely clear picture of his views; his many articles in the organs of the Fédération des travailleurs socialistes, Le Prolétaire and its successor Le Proletariat, show him as one of the most irreconcilable of the exCommunards and at the same time opposed to Guesde's Marxism. This combination of radicalism and anti-Marxism might have been produced by anarchist influence, but there is no convincing evidence to this effect. His role in the 1890 's, after he had separated from Brousse and Malon and had founded his own party, might make it more plausible that Allemane too was somewhat under the spell of anarchist tendencies; especially the efforts of the Allemanists to stay close to the labor unions $^{2}$ - preference for industrial over party organization has often been found with anarchists - and the particularly bitter opposition of

1 Richard Hostetter (op. cit., p. 271) quotes the Italian socialist writer Osvaldo Gnocchi-Viani to the effect that as early as April 1872, Guesde was very successful as a propagandist in Rome, due to his "stringent and impassioned Marxist dialectic." On the other hand, Samuel Bernstein (op. cit., p. 102) contends that in his exile period "Guesde was much nearer to anarchism than to socialism" and supports his contention with a good deal of material (pp. 101ff.). Some of the passages quoted by Bernstein show Guesde in opposition to the General Council, but this may have resulted from purely personal reasons, as a consequence of the intrigues of Dentraygues whom the General Council employed as his agent and who turned out to be a police informer. That Guesde, in this period, considered the state useless and its destruction necessary, and regarded universal suffrage as a fraud, would indicate an option for Bakuninism and against Marxism in a person who saw the core of the issues clearly, but not necessarily in one of the uninitiated, and in the early 1870's Guesde certainly was in the latter category. In his address, written for the General Council, on the Commune defeat, Marx himself had proclaimed it as one of the lessons of the Commune that "the working class cannot simply lay hold of the ready made state machinery and use it for the workers' own purposes" (The Civil War in France, London: Martin Lawrence, 1933, p. 37), but has to destroy a large part of it; Engels later stated that during and immediately after the Second Empire the mistrust against universal suffrage was general among French socialists because of its misuse by Bonapartism. See his introduction to Karl Marx, The Class Struggle in France (1848-50), ed. Palme Dutt, London: Martin Lawrence, n.d., p. 20. The thin though vitally important line which separated Marx's and Bakunin's positions in practice - affirmation or rejection of legal and public political action - was probably not always very clear to the soldiers and subalterns of the revolutionary movement in the immediate post-Commune period.

2 See Maurice Charnay, Les Allemanistes, Paris: Marcel Rivière, 1912, pp. 58ff. 
the Allemanist group to the alleged overestimation of the parliamentary game by the Broussists may be interpreted in this sense, but here, too, different interpretations are possible.

In any event, the leadership of Brousse and Malon indicates that the tendencies which entered into the ideology of the Féderation des travailleurs socialistes made the break with anarchism incomplete. Brousse especially must have believed that he retained the essentials of his former anarchist creed, however thoroughly he had changed his views on means and methods. Brousse had developed a "theory of public services". 1 This theory was a plan for the transformation of the monetary economy, based on profit seeking, into an economy based on the principle of service, with the public powers putting all the necessities of life gratis at the disposal of the citizens. Brousse expected this new task to transform the public power from a rule over persons into an administration of objects. The transformation itself was in consonance with Marxian expectations, but in the Broussist scheme, contrary to Marxist theory, the process would not be postponed until after the proletariat was in safe possession of the political power, and would not, dialectically, follow a period in which state power over persons had reached its climax of oppressiveness in the form of a dictatorship, but the process might begin here and now; to start it, Brousse demanded development of public utilities in municipal ownership. The will to start the movement toward the final goal in present-day society made Brousse's basic idea compatible with gradualism; the placing of the emphasis on local economic activity rather than on national legislative action kept the distance from anarchism much shorter than that which separated the latter from Marxism. But though in some sense gradualistic, Brousse's position did not preclude the assumption that the movement toward the goal could be - or the postulate that it should be speeded up by revolution. The evidence leaves no doubt that in the first half of the 1880 's Brousse indeed considered himself a revolutionary. ${ }^{2}$

${ }^{1}$ La Propriété Collective et les services publics, Paris: Marcel Rivière, 1883.

2 Brousse himself tried to define his attitude toward anarchism in a reply to L. Noterman, who called himself an anarchist although he held no brief for the anarchist "propaganda of the deed". Brousse wrote: "If one takes the word anarchist in its etymological sense... I would call myself an anarchist, as Noterman does, for my ideal is a society which is not governed. In this sense we, of the Workers' Party, are all or nearly all anarchists.

But if I desire a society which is not governed, I still want a society which is administered. Administration is not government. I want the role of the state to be generalized (je suis pour la généralisation du rôle de l'Etat) because this generalisation is the universalisation of public service, that is scientific communism. The anarchists, however, who were my target and whom I have hit (que $j$ 'ai visés et touchés), are on the contrary antistatists and even amorphists." (Le Prolétaire, July 10, 1883.) 
Malon may have moved farther away from anarchism than Brousse, but his skepticism about the state had not disappeared. As late as 1886, in a critical discussion of the picture of socialism drawn by Lassalle and Schäffle, he expressed the view that "under the actual conditions of men and affairs, the state will, for the most part, have to limit its role to that of a guarantor (affirmeur) and controller." "In all that touches politics", Malon said in the same booklet a little later, "the socialists obviously are inclined to disarm the state as a ruler of men, only to arm the state as an administrator of objects (administrateur des choses) and especially to constitute the Social Commune. Thus they are libertaires."2 Like Brousse, Malon had a preference for the local community over the national state. "In the socialist concept, the local community ... acquires great political and economic importance and becomes the genuine social unit (devient la véritable unité sociale) ... The community will be a powerful aid in the general transformation of human relations, and when it has attained its greatest effectiveness (quand elle sera dans son plein fonctionnement), the role of the state will be reduced to the administration of national public services, conforming to the pact of federation [among the communes], and to the representation of the nation in the amphyctionic council of peoples which have been freed from monarchy as well as from capitalist exploitation of man by man."3

No Marxist would have drawn such a picture of depolitization of society without adding that it could become reality only after the dictatorship of the proletariat had done its work - and this was definitely not the opinion of Malon or Brousse, and even hardly the opinion of Allemane. The time at which these passages were written, the middle of the 1880's, makes their content all the more remarkable: Years had lapsed since Malon had broken with anarchism, yet the bias against the state had survived in his mind.

1 Benoitt Malon, Le Socialisme réformiste, Paris: Derveaux, 1886, p. 25. This remarkable pamphlet, which aside from comments on the thoughts and actions on Malon's socialist contemporaries also contains interesting and original ideas on utopian socialism, has not received much attention, probably because it does not seem available anywhere except in the Bibliothèque Nationale. This rarity is apparently the result of confiscation in consequence of a lawsuit which the publisher of the first edition brought against Malon when the latter arranged for a reprint. See rapport of the Préfecture de police, contrôle générale of March 23, 1886, and contrefaçon of March 24, file no. 67471 at the Préfecture de police, Paris.

2 Malon, op. cit., p. 33. In its specific meaning, the term libertaire signifies an anarchist or, in reference to a later period, a revolutionary syndicalist. But the term can also be used in a somewhat broader sense, indicating a tendency of thinking rather than a dogmatic position, and therefore including persons who do not want to abolish the state but to deprive it of all or most of its coercive functions.

3 L.c., p. 49. 
IV

\section{THE PARTY TURNS POSSIBILIST}

The collectivist majority which had drawn the line against Moderates and anarchists and had formed the Féderation des travailleurs socialistes consisted of people diversified in their views, and its organizational unity could only have been preserved under a leadership as patient as that of Karl Marx in the International Workingmen's Association during the 1860 's. No such leadership was available now in the French workers' party, and the man least suited for such a role was the protagonist of Marxism, Jules Guesde. Nor was Karl Marx, who even in the last years of his life had considerable influence on Guesde and on the latter's comrade in arms, Paul Lafargue, in a mood to use this influence in the sense of admonition to patience. The conflict with Bakunin, who was a more formidable opponent than the Proudhonians and other adversaries with whom Marx had previously had to measure his strength in the International, seems to have brought Marx's inherent but often restrained inclination to canonize his own beliefs into the open. Least of all was Marx willing to preach to his French disciples tolerance toward men whom, like Brousse and Malon, he still suspected of Bakuninism in view of their past. ${ }^{1}$ The "minimum program" which he had drafted or had helped Guesde and Lafargue to draft, was obviously intended to serve as an expression of the orthodox creed, and it was given to the French leaders as a statement of beliefs to which all French socialists should be converted. Outside the Marxist circle, the French socialists did not take kindly to this attempt, all the less so because Marxian hegemony was suspected to mean German hegemony within the international socialist movement. "Marx and Engels hardly concealed their efforts to extend the hegemony of German socialism over the various workers' parties of Europe."2 Although this was hardly a correct reading of Marx's intensions, yet it seems to have been the interpretation which the attempt to impose the "minimum program" on the Fédération des travailleurs socialistes received in France.

1 As late as 1889, Friedrich Engels, whose views on this point were undoubtedly identical with those of Marx, wrote in a letter to Friedrich Sorge that the conflict between Guesdists and Broussists was "again the old rift which split the International". See Karl Marx and Friedrich Engels, Selected Correspondence, Moscow: Foreign Languages Publishing House, 1956, p. 486. Wilhelm Liebknecht, in quoting this statement, adds the comment that Engels considered Brousse "still the old anarchist" (Wilhelm Liebknecht, Briefwechsel mit Karl Marx und Friedrich Engels, ed. Georg Eckert, The Hague: Mouton, 1963, p. 313). This would have been less of a mistake in 1882 than in 1889.

Sylvain Humbert, Les Possibilistes, Paris: Rivière, 1911, p. 9. 
Was personal antagonism to Guesde or fear of the influence of Marx the stronger impulse in the minds of those members of the party who finally broke with Marxism? ${ }^{1}$ In any event, from the Congress of Rheims in 1881 on the tension grew between the two factions and reached its climax at the Congress of Saint-Etienne in 1882, when the Guesdists had to leave the Féderation and founded their own party at a congress at Roanne under the name of Parti ouvrier français.

This development has often been described. What has not been fully explained, however, is the position which the anti-Marxist majority took right after the split, and therefore the true nature of the split itself. It has been assumed that Paul Brousse and Benoit Malon took the same position in the early 1880 's which they, or Jaurès, or Bernstein took a decade later or around 1900. But the issues of 1882 were not identical with those in the controversies over the Voraussetzungen des Sozialismus, over Millerand or at the Dresdener Parteitag.

The differences in beliefs between the factions at Saint-Etienne are well defined in two statements by Brousse. The one concerned the requirement and enforcement of orthodoxy: Was there a body of socialist doctrines sufficiently obvious in its validity and acceptable to a large enough group of workers to be proclaimed as the official faith of the movement? The Marxists of course affirmed this and consequently insisted on a centralized organization committed to a well-defined creed. ${ }^{2}$ But Brousse thought otherwise: "It is necessary that everybody renounces the foolish hope to see the whole proletariat enter into the narrow orbit of his own thought, to mould the ideas into the rigid form of a particular doctrine." 3 The Broussists, too, believed that there were

1 In the following passage from the "acte d'accusation", which the Comite de national had drawn up to prepare the case for the expulsion of the Guesdists, the Marxist influence appears as the main charge: "A reconciliation is impossible. One cannot reconcile water and fire.... They are the ultramontanes of socialism. The ultramontanes cannot obey the law of their country because their chief is in Rome. The Marxists cannot obey the decisions of the party, because their chief is in London. - One cannot reconcile the Workers' Party with Marxist fanaticism any more than in the liberal world (dans le monde bourgeois) it is possible to reconcile clericalism with the state. There is only one solution: Separation of church and state, and the exodus, either voluntary (raisonnable) or forced, of the Marxist capuchins from the state of the socialist workers." (Seilhac, op. cit., p. 106.)

'See for instance the following statement by Jules Guesde: "There are noxious ideas (idées ennemies) which under their ancient name of 'federalism' and under their new names of 'communalism' and 'autonomy' still are an obsession in the brains of a number of workers and which tend to make any revolutionary action of the proletariat impossible by their disintegrating effect (en l'émiettant). L'Egalité, frankly and scientifically committed to centralization, sets itself the task of demolishing these ideas." (L'Egalité, December 11, 1881.)

${ }^{3}$ Le Prolétaire, November 12, 1881. 
some fundamental points to which all socialists should adhere, as the program adopted at Saint-Etienne shows. These points included the belief that the emancipation of the working class can only be achieved by the workers themselves, that to this end it is necessary to have a workers' party, that the emancipation of the working class requires the socialization of the means of production, and that this goal must be pursued with all means available, including revolution. But within this fairly wide framework they wanted to give the local groups of the party complete freedom of interpretation and action, and therefore adopted a very decentralized form of organization.

The second point concerns fundamental strategy: "I prefer to abandon", Brousse wrote, "the all-at-once idea that has been followed up to now and which has led us to nothing at all. We should break up the ideal we want to realize into aims realizable in stages, to designate some of them as capable of immediate fulfillment and thus bring part of our program within the limits of possibility (immédiatiser en quelque sorte quelques-unes de nos revendications pour les rendre enfin possibles). We should no longer exhaust ourselves by merely marking time, or ... remain perched on the towers of Utopia and never see anything concrete and tangible accomplished."1

Brousse called this "the policy of the possible". Guesde soon attached a derogatory implication to this term, designating the Broussists as "possibilists", a name which they willingly accepted. "It is really necessary", Guesde wrote, "to worry about making our postulates possible (s'agit-il donc de rendre nos revendications possibles)? Will there be room in the socialist ranks for a new sort of opportunism? Is it possible, under the pretext of electoral successes, with the slogan of possibilism (sous couleur de possibilisme), to question the gaining of ground by revolutionary socialism during the last three years, since the congresses of Marseille and Le Havre?"'

\section{V \\ POSSIBILISM WAS NOT YET REFORMISM}

What, then, was the nature of "possibilism"? It had adopted the basic concept of gradualism to the extent of believing that socialists did not have to wait for the revolution before trying to improve the workers' lot, and that such improvements were effective preparations for the attainment of the final goal. This belief was inconsistent with revolutionary dialectics in the sense in which the growth of the evil, up to

${ }^{1}$ Le Prolétaire, November 19, 1881.

${ }^{2}$ L'Egalité, December 11, 1881, quoted by Sylvain Humbert, op. cit., p. 6. 
the point at which the tension resolves itself in revolution, appears as the necessary condition of progress; "small reforms", then, would in effect be reactionary because they lessen the tension and thereby delay the revolutionary solution. Few Marxists, to be sure, and certainly neither Marx himself nor Jules Guesde, have consistently held to this rigid dialectical creed; 1 it is nevertheless true that only this creed supplies a solid foundation for the belief in the inevitability of social revolution. Of course, nobody has to be a dialectician in order to believe that some circumstances may lead to revolution; to deny that, one would have to be blind to history. But the reformist, in contradistinction to the dialectician, sees no fundamental reason why circumstances should not be so altered as to make revolution unnecessary. ${ }^{2}$

In this sense, the Possibilists were not reformists in the early 1880's. They not only called themselves "revolutionary socialists", which in itself might have merely signified that they wanted to take up the tradition of the Great French Revolution or simply that they were striving for a fundamental social change - even the German Social Democrats as late as 1906, when they certainly had ceased to be revolutionaries, closed their congresses with cheers to the "revolutionary Social Democracy" - but the tone and content of Le Prolétaire and Le Prolétariat show that their revolutionary creed was hardly less strong than that of the Guesdists. This belief in the inevitability of revolution, separated as it was from its roots in dialectics, may from the outset

1 In the next decade, Guesde himself was to supply a striking example of deviation from dialectics, when he proposed a program destined to protect the property of the French small agriculturist, and thereby to prevent that concentrattion of property which in Marx's opinion was the first prerequisite of the growth of social tension. See Carl Landauer, "Early Erosion of French Marxism", in: International Review of Social History, VI, 1961.

- Another difference between Broussists and Marxists, which however played no direct role in the controversies, was brought out by an intelligently written police report in 1887 ; it would be equally valid for the period immediately before or after Saint-Etienne. "The two schools", wrote the police officer, "although in agreement about the final goal, the revolution, differ in regard to the means. The doctrinaires of the Parisian group [the Guesdists] think only of overthrowing the institutions now in existence (l'état des choses actuelles), leaving for a later date the determination of what they want to put in their place, whereas the members of the Union féderative [the Broussists] want to study in advance the social organization which they wish to create on the day after the revolution." Report of the Préfet de police of Paris to the Minister of the Interior of September 9, 1887, Prefecture file Carton 31, 177300 - A-17.) Indeed, the Broussists not only refused to wait until the day after the revolution before beginning to put their theorie des services publics into effect, but this theory was also presumed to determine the character of the future society with much more detail than had ever been given in the Communist Manifesto or the Anti-Dühring, and consequently violated the Marxist ban on "utopianism". 
have been doomed to wither, as it eventually did, but it had not withered at the Congress of Saint-Etienne and it did not do so in the years immediately following.

Under any circumstances, Malon and Brousse might have found it difficult to cut loose too quickly from their past of anarchist radicalism; but the most powerful force that kept the belief in the inevitability of revolution strong in the minds of most socialists, of the rank and file as well as of the leaders, was again the Commune experience of the implacability of the bourgeoisie. It was taken for granted that any attempt at reforming society by pacific means would be ultimately unsuccessful. A contributor to Le Prolétaire, S. Deynaud, wrote for instance in an article on the Congress of Saint-Etienne:

"The workers' Party must attempt the peaceful conquest of the political powers in the state and the administrative powers in the community with the avowed intention to use them for the attainment of the final goal.

In this attempt, the Workers' Party will run up against (se heurtera) government brutalities which palpably negate the natural right of association and public expression of thoughts. Therefore the party must prepare itself to respond with force to provocation by force."2

Next to the memory of the fusillades, it was the desire to establish, beyond any doubt, the identity of the socialist movement as the expression of workers' class consciousness that delayed the development of the Broussist party toward conscious reformism. Just as in Germany in the 1860's Lassalle had found the workers' movement largely under the tutelage of the Fortschrittsparte ${ }^{3}{ }^{3}$ so in France, two decades later, the Parti radical with its annex called Parti radical-socialiste, had a large working class following. When the Commune fighters returned, many of them joined the Radicals rather than the socialists, especially after a separate organization of moderate ex-Communards, the Alliance socialiste républicaine, had proved short-lived. The expressions of extremist sentiment and emphasis on the revolutionary creed of the workers' party helped to keep the line between socialism and left democracy clear; the professions of great radicalism also served the purpose of drawing a line against the Proudhonian tradition which the Broussists had fought together with the Guesdists.

1 Italics in the original.

2 Le Prolétaire, September 23, 1882.

3 This is true although the Arbeiterbildungsvereine, which represented most of the politically conscious workers, had emerged from the tradition of an autonomous working class movement: the Arbeiterverbrüderung of 1848-9. See Frolinde Balser, Sozial-Demokratie 1848/49, Stuttgart: Ernst Klett, 1962, Vol. I, pp. 487f. 
The expressions of revolutionary extremism in Le Prolétaire and Le Prolétariat during the first years after Saint-Etienne are numerous. Jean Allemane apparently had the prevailing influence on editorial policy, but it does not seem that Brousse or even Malon opposed his radicalism in this period. ${ }^{1}$ An especially interesting example can be found in the address with which Le Prolétaire greeted a delegation of British trade unionists who came to Paris for a visit. The Possibilists always tried to establish close international ties, and therefore the bulk of the address stressed the community of interests between the workers of the two countries in their struggles with their employers. But the French party still considered it necessary to add a qualification:

"Undoubtedly, workers of England, we differ about the means. You expect more than we from the daily struggle in the industrial field (la lutte professionnelle) and from parliamentary action for the gradual and peaceful achievement of the reforms which you demand. But we, who live in a country which for ninety years has seen the most violent political changes, we who are confronted with a bourgeoisie which has never responded to our demands in any other way than by the gun and the dungeon, thus compelling us to obtain by force, in bloody revolutions, what little freedom and equality we possess, we believe less than you do in the efficacy of pacific means. Nevertheless, we are still trying to confine ourselves to a policy of warning the French bourgeoisie, and this course should bring us closer to your position - What brings us still closer together is our goal."'2

That even Paul Brousse at that time was far from a reformist position, he showed in an article written in 1884 on the occasion of the prolongation, by special ordinance, of the mandates of the Paris city councillors. $\mathrm{He}$ regarded this prolongation as illegal but welcomed it because it gave the socialist representatives on the council the possibility of staying in office somewhat longer. The policy of the party to accept this advantage when other political groups did the same, hardly required

${ }^{1} \mathrm{Up}$ to one or two years before the scission between the Allemanists and the Broussists, there is hardly any evidence of dissension over issues within the Fédération des travailleurs socialistes. When Georges Weill maintains that the majority at Saint-Etienne was "united less by belief in a new kind of tactics than by antipathy to the arrogance of the Guesdists" (op. cit., p. 243), he probably judged the events of $\mathbf{1 8 8 2}$ too much in the light of later developments. The majority seems to have agreed on the principle of Possibilism, as formulated by Brousse, with the understanding that this did not detract from the will to wage the class struggle ultimately with revolutionary means.

2 Le Prolétaire, November 25, 1882. The address was published as a bilingual pronouncement. The English version, however, is a rather poor translation, and it has therefore been necessary to use primarily the French text. 
a defence with philosophical arguments; yet Brousse took the opportunity to discuss the attitude of the party toward bourgeois legality: "For the partisans of legality there exists really no mandate where no vote has been taken, surrounded by all the formalities which the law prescribes. But the situation looks different to a revolutionary party like the Workers' Party, because this party regards the legality, imposed by the ruling classes, and the formalities with which it is surrounded, not as a manifestation of right (droit $\left.{ }^{1}\right)$ but as simple facts of which it is necessary to take cognizance merely because they are important determinants of political development ... In the eyes of the party, this assembly is a position which we must occupy; it is necessary to have its membership penetrated by socialists. Through what means? Through all means: legal and illegal, by force and by the vote."2

This contempt for bourgeois legality was not quite consistent with the attempt to change social conditions within the bourgeois state through the use of the law, as implied especially in Brousse's philosophy of gratuitous social service to be introduced in municipalities. Because Brousse's ideas were inconsistent in themselves, they were also unstable, and the contradiction was finally resolved by Brousse becoming a true reformist.

In one instance the desire to maintain an extremist position brought the Possibilists even close to the glorification of an act of individual terror. A man of apparently unbalanced mind, Max Hödel, had made an attempt at the life of the German Emperor William I, and Bismarck used this crime to win support for his anti-socialist policy. For the German Social Democratic Party it was a matter of self-preservation to treat Hödel's attack as an act of insanity, and this approach would also have offered the only chance to save the man's life if such a chance had existed at all. But Le Prolétaire took the Social Democrats to task for treating the régicide Hödel as a "demented person, an idiot, a halfanimal" and praised him for having refused a clergyman's support and, upon hearing the death sentence, "instead of shouting 'long live Germany', 'long live Ireland' or 'long live France', having exclaimed: 'Long live the Commune'",3

1 Here it is important to remember that the French term droit, like the German term Recht, means right as well as law.

${ }^{2}$ Le Prolétaire, January 12, 1884.

Le Prolétaire, January 5,1884 . The reason for the reference to Ireland was the case of the Irish patriotic terrorist O'Donnell whose case was discussed in the same article. Although criticising the British trade unionist Shipton and the German Social Democrats for their attitudes toward these terrorists, Le Proletaire emphasized that the French party would continue its friendly relations with the British labor unions and the German Social Democratic Party. 
Although there is no evidence that in the early 1880's Allemane, any more than Brousse, was the driving force behind this radicalism, he was undoubtedly in full sympathy with the tendency. In 1887 - when perhaps Brousse was no longer in favor of quite that type of propaganda - Allemane published an article which, as he must have realized, would be regarded as an outrage by a large part of French public opinion. The title was "Let us tear down Notre Dame!"

"Although we shall be labeled infidels and barbarians, and all the guardians of the old and the sacred will cry out against us, we demand that Notre Dame be torn down and that in its place a new structure be erected - not dedicated to the glory of a god which the brain of 19 th century man has forever placed in the category of evil tales and inventions, but to the glory of something greater and more useful: We are thinking of Labor ... we request, purely and simply ... that in the place of the monster of stone erected in honor of the religion which, inspite of its god of peace and mercy, is the most savage of all, there appear, grand and majestic, the only monument suitable for a democratic, egalitarian and pragmatic society: a Palace of Labor."1

Perhaps Allemane sensed that in $\mathbf{1 8 8 7}$ the tendencies toward conscious reformism were already strong in the Féderation des travailleurs socialistes and wanted to spike them by using the official organ of the party for an attack upon values treasured by middle class France, in the hope that the repercussions might drive the party back to the left.

\section{VI}

\section{THE TURN TOWARD REFORMISM}

During the second part of the 1880's, Possibilism became reformism. At the beginning of the decade, the party believed in the inevitability of the revolution and merely wanted to use the time before the revolution was ripe for the improvement of the workers' condition and for the preparation of post-revolutionary forms of living; toward the end of the decade the party believed that revolution could be replaced by gradual reform. As nearly as any single year can be recognized as the time at which this process became evident, it is 1885 or 1886 , and to the extent that any single leader can be regarded as the pioneer of the development, it is Benoît Malon.

In 1885 Malon founded the new Revue Socialiste. ${ }^{2}$ The role of this

1 Le Prolétariat, January 1-8, 1887.

2 In 1880, he had already attempted to found a magazin under that name, which, however, soon ceased publication. 
mouthpiece of French socialism as a promotor of reformism was not so clear in the beginning as it became later; moreover, at all times this role was modified by a concern for socialist unity. Just the same, there can hardly be any doubt that Malon's purpose in founding the magazine included the elaboration of a more consistent non-Marxist concept of socialism which under the circumstances could only be a reformist concept.

Malon's motives became particularly clear in 1886 when he published his pamphlet Le Socialisme réformiste. There is no explicit renunciation of revolution in this booklet, but the emphasis on reforms is now so strong as to leave no doubt that their achievement is regarded as the principal means to move toward the final goal: 1

"...it behooves those who understand their times (ont l'intelligence de leur temps) and have the vision of the tomorrow, to concentrate on the creation, in this country, of a great reformist trend (courant). With the end of the squandering of public funds and of the adventures, it will be necessary to have immediate economic reforms and a rapid republicanization of work and distribution (échange): There, and only there, lies republican salvation and social salvation." 2

In 1887, Malon issued a statement which goes one step farther in the same direction, by pointing to a reform policy as a method to make

1 The title alone would not show the change conclusively. Although a true revolutionary would not have identified himself with anything he called reformism, the term, as understood shortly after Saint-Etienne, might not have implied more than a will to introduce or demand reforms here and now.

2 Malon, Le Socialisme réformiste, p. 52. The drive for reforms had received a strong impulse from the realization that France was lagging behind Germany in meliorative social legislation, and that the bourgeois parties were in no great hurry to remedy the deficiency. "Prior to 1889 , the republican party had redeemed its two promises to the workers: It had organized elementary instruction and assured liberty to labor unions. But the laws for the protection of workers had hardly advanced beyond the state of 1874 . This lack of progress is in part explained by the overshadowing importance of political, religious and colonial questions, but the prevailing ideas about the limited role that the state could legitimately assume were also a factor..." (Georges Weill, op. cit., p. 430). The socialists had good reason to consider this backwardness not only a grave injustice but also a danger for the republic, since it made the workers susceptible to the promises of anti-democratic groups, as became particularly evident in the Boulanger crisis. In Malon's booklet, the passage quoted in the text is preceded by the following sentences: "If the republic has lost the magic of its name, if a part of the French people, after having suffered so much for the republic, seems for a moment to question its capability (efficacite), this is not only due to the colonial expeditions (expeditions lointaines), to the deficits, to the squandering of funds, but also to the absence of all reforms." (Malon, Socialisme réformiste, p. 51.) 
revolution unnecessary. For the Paris International Exposition of 1889, a Social Economic Committee had been formed, which Malon was officially invited to join. He accepted the invitation only on the condition that a subcommittee should be composed exclusively of socialists and have the task "to establish an inventory of ideas and attempts at social reform since the beginning of the century". This should lead to a program "of necessary economic reforms ... which might spare us perhaps a violent revolution, so full of danger for everybody (en faisant, si possible, l'économie d'une révolution violente, pleine de danger pour tous)". ${ }^{1}$

Two years later, under the title "Personal Opinion", Malon published a sort of reformist manifesto in L'Egalité, which at that time called itself "an organ of socialist concentration" and of which Malon, along with Guesde, Lafargue, Longuet and the Blanquist Edouard Vaillant was an editor. ${ }^{2}$ The article starts out with an exhortation to socialist unity, to overcome the dissensions which had arisen during the Boulanger crisis, when some socialists were captivated by the general's promise of social reform, others formed a common front with the bourgeois republicans against the Boulangist attack, and still others remained passive in the hope that the Boulangists and the laissez faire bourgeoisie would destroy each other. Malon criticizes the mutual intolerance of the various socialist factions and then extends the call to bury hatreds even beyond the socialist ranks. France, he argues, is in a triple crisis: national, political and social. "... the times have passed when a strong France could leave herself to her internal revolutions, without fear of foreign dangers ... Today, we are surrounded by powerful and hostile monarchies, we are under the guns of the Triple Alliance... The crisis is also political: The republic, not having shown the capacity to attract popular sympathies by successive, farreaching reforms, is now contested by three million reactionaries or misguided citizens, who are under the influence of unscrupulous manipulators, and the latter are ... attacking the republican government without giving any thought to the possibility that France might be engulfed in the downfall of her free institutions. But the democratic and progressive republic is the basis of our action, and we must be prepared to defend it against the reactionaries as well as against its doubtful saviors. But how shall we defend it, if we are irreparably divided? - From this need for mutual concessions and for unity, there follows the necessity of a clearly reformist social policy. The time for hazardous and unpromising enter-

\footnotetext{
${ }^{1}$ Quoted in Dixneuvième Siècle, June 19, 1887. Malon's condition was first accepted, but he felt that the promise was not kept, therefore he resigned.

2 This Egalité had hardly more than the name in common with the journal which at various times was the principal organ of Guesdism.
} 
prises, for a romantic-revolutionary phraseology has passed. The socialists cannot engage in this anymore without harming their noble cause and endangering the republican liberties which have been gained by sacrifice ... The great electoral battle (comices) of 1889 will soon begin. We are beaten in advance if we go there with programs amounting only to mere declamations or with confuse (disparates) declarations, if we do not know how to put our postulates into an order of gradation (sérier nos revendications) by leaving to the future that which belongs to the future, and by devoting ourselves primarily to demands for economic and social reforms which constitute the platform of the struggling (militant) proletariat and which can be immediately carried out by the public powers. - An appeal to all the proletarian and progressive (novatrices) forces, an open start on the road of reformist socialism will have important results. First, it will lead to immediate amelioration of the sad condition of those who win their livelihood from labor; secondly, it will give the socialist party experience in social matters and also numerical strength. These will prove inestimable advantages and conditions of victory on the day, which is perhaps near, when the socialists will take power from the failing hands of the bourgeoisie, when the latter will be bogged down in difficulties which can be overcome only by a transformation of society, gradual and peaceful if possible, but inevitable in any event." 1

Although the last sentences contain some consessions to the revolutionary tradition, the tenor of the whole article, especially the appeal to the party to leave to the future that which belongs to the future is almost Bernsteinian, whereas the emphasis on the defence of the republic, with the implication that a common front of socialist and non-socialist defenders may be necessary, and the element of Jacobinian patriotism correspond to traits in the thinking of Jaurès.

Paul Brousse must have sympathized with these ideas of Malon's, but he does not seem to have given any demonstrative expression to this sympathy. There were apparently no close relations between the two men in the late 1880 's. This may have been due simply to a sort of division of labor: Brousse apparently concentrated on direct party work, whereas Malon occupied himself exclusively with his literary projects. Possibly, however, there was personal antagonism. The police files contain several hints of such enmity, but they are of a kind which deserves little credence. Another suggestion to the same effect can perhaps be taken more seriously, although it was obviously inspired by malice toward Brousse. In a comment on the split between Broussists and Allemanists at the Congress of Châtellerault in 1890, an anonymous

${ }^{1}$ L'Egalité, February 15, 1889. 
author (signed "C") wrote in Clemenceau's paper La Justice: "At the Congress of Saint-Etienne, Jules Guesde saw himself excluded from the party which he had founded, by a docile majority following the suggestions of his adversary. A little later, it was Benoît Malon who was forced to retire in the face of jealous ambition."1 The "adversary" and the man to entertain "jealous ambition" was of course Brousse.

A possible reason why Malon may have felt - or may have been told by Brousse - that it would be unwise for him to play a great role in the party organization was his relation to Henri Rochefort. The latter had once paid a fine for Malon - imposed as a consequence of a libel suit - and had thereby liberated the impecunious Malon from prison. Malon then wrote for L'Intransigeant, Rochefort's paper. During the Boulanger crisis, however, Rochefort was attacked by the Broussists as being pro-Boulanger, ${ }^{2}$ and since Malon could not separate himself from his benefactor, he might have thought it necessary to avoid all politically very exposed positions.

As far as can be judged from the available material, Brousse seems to have been the principal organizer of reformism, whereas Malon appears as the creator of its intellectual and spiritual foundations. In a valedictory article after Malon's death, Eugène Fournière wrote in La Petite République:

"To the [Marxian] idea of historical necessity, which has for a corollary the class struggle, Malon ... added the idea of justice, which has for a corollary the appeal to the best in men living now."3

Ten years later Jaurès, recognizing the affinity between his own thoughts and those of Malon, wrote in a similar sense:

"First, he reconciled respect for the revolutionary tradition with an appreciation (sens) of the daily work for reform and progress ... At the same time, he affirmed the need for social morality, and here, citizens, lies a truth of which we must become every day more clearly aware. Socialism must be superior to present society not only through the superior value of the goal for which we are striving, but also through the superiority of the means which we employ in our struggle against that same society. Through virtue, in the social and free sense of the word, through work, through faithfulness to our word, through solidarity, through heroic courage, through culture of thought and will must we furnish

1 La Justice, October 10, 1890.

2 See for instance a report in Le Cri du Peuple of October 9, 1887, about an antiBoulanger meeting at which Brousse bitterly attacked Rochefort.

- La Petite République, September 17, 1893. 
proof that we are already above the society of today. By the means which we employ we are building a superior society, and to this better society Benoit Malon will have made some of the most effective and noble contributions through his deeds, through his thoughts, through his sense of responsibility (conscience) and through his almost infinite goodness." 1

These sentences in Jaurès's article reflect a kind of thought which was less frequent among the reformists of the pre-1914 period than among those of the interwar era. After 1917, the focus of the controversies between Communists and democratic socialists - now nearly all of them reformists of one variety or another - focused in the means-end problem: Can the good society be created by methods that violate the ethical principles which are recognized even under capitalism? Can a society without violence and oppression be created by first escalating violence and oppression, through the abolition of such devices as free voting and guarantees for civil liberty - devices by which mankind has succeeded in minimizing violence in domestic policy disputes? In that later period, the reformist position was based mainly on the argument that social revolution, which in the event of victory was almost bound to end in dictatorship, would lead to intolerable physical and mental suffering and to moral degradation, and thus would destroy the foundations on which alone the new society could be built. The pre-1914 reformists, to the extent that they openly professed the intention to forestall the revolution or reduce its likelihood, spoke less of its inhumanity and more of its impracticality: Conditions would not be ripe for revolution for a long time to come, in the meantime revolutionary propaganda could only harm the party's chances to attract support from strata marginal to the proletariat. Why impair the prospects of reform work, which may even cause present society to "grow into socialism", by indulging in empty revolutionary slogans or cultivating an unrealistic belief in an overthrow of existing society? This was, on the whole, the tenor of Bernstein's writings; only here and there do we find utterances by reformists like Malon's warning, in 1887, that the revolution would be "full of dangers for everybody", or Jaurès's insistence, in 1913, that socialists are committed not only to striving for morally superior goals but also to the use of morally superior means.

The reason why the prewar reformists spoke less of the cruelty of revolutionary methods than their successors after the First World War was not, of course, any lack of humanitarian concern; rather, the consequences of revolutionary methods were less clear and therefore the reasons for humanitarian concern seemed less compelling. Although

${ }^{1}$ L'Humanité, October 11, 1913. 
Marx had indicated that the "dictatorship of the proletariat" must follow the victorious revolution, many socialists continued to think of social revolution as of the opening of a door to political as well as social democracy. Without its sinister sequel, revolution appeared more as a glorious opportunity to accept risks and sacrifices for a great cause than as a use of means contrary to the ideal of a peaceful and free society. For an object lesson in the means-end problem of revolution, the socialists had to remember the Jacobin terror, but few socialists - at least in Western and Central Europe - thought that anything like it would become necessary after a revolutionary seizure of power by the proletariat. Rosa Luxemburg's horror over Bolshevik practice reveals the self-deception to which the humanitarians on the extreme left had fallen victum, but even the right wing of the socialist movement did not have a very vivid idea of the consequences of revolution. Malon and Jaurès, too, failed to visualize these consequences clearly, but by their ethical idealism they prepared the basis for the attitude which after the First World War the reformists took toward the means-end problem when it became visible in the hardest possible contours.

The Possibilists became reformists in part because their original combination of belief in the inevitability of revolution with the "policy of the possible" was too inconsistent to endure. The turn toward reformism, however, was not merely the consequence of unfolding contradictions in the initial position, but to some extent also a reaction of Brousse and his friends to developments on the French scene, especially to the increasing desire of the French workers for such benefits as their German comrades were drawing from social security legislation and to the danger for the republic put in the limelight by the Boulanger affair. Because these facts called for a sufficient attenuation of class struggle ideology to permit cooperation with reform-minded and sincerely republican groups of non-socialists, they operated against any attempt to solve the basic inconsistency in original Possibilism by a return to an exclusively revolutionary philosophy and favored the trend of thinking toward the belief in reforms as means to socialize society without revolution.

French Possibilism, which developed into reformism, has one of its historical roots in anarchism. The anarchist beginnings of Brousse and Malon, although definitely a matter of the past in the 1880's - a bewältigte Vergangenheit, if it is permissible to use that slogan from recent German history - still exerted an influence on their thinking and on the policy of the Féderation des travailleurs socialistes. In the early phase, the heritage of anarchist extremism which expecially Brousse brought into the new party, helped to prevent a premature tendency toward moderation - premature in view of the sentiment of a large section of 
the working class. In the second phase the emphasis, inherited from anarchism, on social progress outside the state machinery helped to apply the pragmatic orientation of incipient reformism at a time when socialist influence in the national legislature was still too limited for immediate great results. Although the idea of a universal gratis supply of public services was of course unrealizable, the concentration on work in city councils proved a healthy thing for a party which could vindicate its emphasis on reform only by achieving reforms. At all stages the deep aversion from any form of dictatorship, so important an element in the anti-Marxism of the Bakunin period, has assisted the Fédération des travailleurs socialistes in developing a philosophy which refused to sacrifice individual liberty in the quest of social justice.

It has occurred in the history of socialism that anarchist tendencies formed a useful counterweight to the tendencies toward excessive centralization inherent in other schools of collectivism. To be sure, the anarchism of the John Most variety has not only played a sinister role in the labor movement but has also operated against social amelioration by impairing the workers' will to use political means for the improvement of their lot; it would also have been a misfortune for labor if Bakuninism had ever achieved a full victory. But a tendency toward anarchism is not in all situations a clear opposite to reformism; there can be conditions in which a modified anarchist influence operates as a force promoting the evolutionary rather than the revolutionary tendencies in socialism. This is one of the lessons to be drawn from the origin and development of French Possibilism.

When the foregoing article was already in type, I was permitted - through the courtesy of the Internationaal Instituut voor Sociale Geschiedenis - to inspect a letter written by Paul Brousse in 1880 to Garcia Viñas. The letter, which was in part published by Max Nettlau in German translation in his book Anarchisten und Sozialrevolutionare (1931), explains why Brousse was then transferring his allegiance from the Bakunin type of anarchism, as represented by the Féderation jurassienne, to a broad socialist movement which he envisioned. The letter shows Brousse to be, at the time of writing, an anti-sectarian and pragmatist, but still a revolutionary pragmatist: His concern is the establishment of a united front of all believers in collectivism and communal autonomie for the decisive struggle against the bourgeoisie; the latter is viewed essentially as One Reactionary Mass. The letter is a clear description of the possibilist position - the term possibilisme actually occurs in the letter - when it has not yet begun to develop into reformism and when Brousse even believed that he could establish unity of action with Guesde and his friends. 